\title{
STUDI KUALITAS AIR TANAH BERDASARKAN SIFAT FISIK DAN KIMIA MENGGUNAKAN ANALISIS HIDROGEOLOGI DAN HIDROKIMIA DI JAKARTA BARAT
}

\section{QUALITY STUDYOF GROUND WATERBASED ON CHARACTERISTICSIN PHYSICSAND CHEMISTRYBY USING METHODOF HYDROGEOLOGYAND HYDROCHEMISTRY IN WEST JAKARTA}

\author{
Albar Karismawan ${ }^{1}$, Dyah Nindita Sahdarani ${ }^{2}$, Mochammad Prahastomi M.S ${ }^{3}$, Tantowi Eko Prayogi ${ }^{4}$ \\ ${ }^{1,2}$ Program Studi Geologi, Fakultas Matematika dan Ilmu Pengetahuan Alam, Universitas Indonesia, Depok, Indonesia \\ ${ }^{3,4}$ Balai Konservasi Air Tanah (BKAT), Jakarta, Indonesia \\ Email: albar.karismawan@ui.ac.id
}

Diterima: 20 Mei 2021. Disetujui: 19 Juni 2021. Dipublikasikan: 24 Agustus 2021

\begin{abstract}
Abstrak : Kajian Air Tanah di Jakarta Barat untuk mengetahui kualitas air tanah yang biasa digunakan warga menggunakan nilai standar Permenkes No. 492 Tahun 2010, melalui parameter Fisik dan kimia. Penelitian ini berfokus pada pengukuran akuifer bebas. Penelitian ini bertujuan untuk memetakan kualitas airtanah dengan metode hidrogeologi dan hidrokimia. Analisis hidrogeologi untuk memetakan muka air tanah berdasarkan pengukuran kedalaman air tanah. Data hidrokimia untuk melihat kondisi salinitas, jenis air, serta tingkat intrusi air laut di daerah penelitian. Berdasarkan pengukuran yang dilakukan penulis pada bulan Maret 2021, kedalaman air tanah terdalam adalah di Kelurahan Semanam dengan kedalaman 9,3 mbmt, dan yang paling dangkal berada di Kelurahan Rawa Buaya dengan kedalaman 0,2 mbmt. Berdasarkan pengukuran penulis, kualitas airtanah di Jakarta Barat sangat memprihatinkan. Kelurahan Roa Melaka memiliki air yang bau, serta kandungan Klorida, dan Natrium, yang tinggi. Kelurahan Duri Kepa dan Jelambar memiliki pkandungan besi yang tinggi, dengan kadar 0,4 mg/l dan 1,65 mg/1.
\end{abstract}

Kata Kunci : Akuifer Bebas, Hidrogeologi, Hidrokimia, Kualitas Air Tanah

\begin{abstract}
Groundwater Study in West Jakarta to determine the quality of groundwater commonly used by residents. This study using standard law fromPermenkes No. 492 of 2010, through physical and chemical parameters. This study aims to map groundwater quality using hydrogeological and hydrochemical methods. Hydrogeological analysis to mapping the groundwater table based on groundwater depth measurements. Hydrochemical data to see the conditions of salinity, type of water, and the level of seawater intrusion. Based on in March 2021, the deepest groundwater depth in KelurahanSemanam with a depth of $9.3 \mathrm{mbmt}$, and the shallowest is in KelurahanRawaBuaya with a depth of 0.2 mbmt. Based on the author's measurements, the quality of groundwater in West Jakarta is very concerning. The village of Roa Melaka has smelly water, and high chloride and sodium content. InDuri Kepa and Jelambar have high iron content, with levels of $0.4 \mathrm{mg} / 1$ and $1.65 \mathrm{mg} / \mathrm{l}$.
\end{abstract}

Keywords : Free Aquifer, Hydrogeology, Hydro Chemistry, Ground Water Quality

\section{PENDAHULUAN}

Manusia bergantung dengan air bersih dalam melakukan berbagai macam aktivitasnya. Aktivitas tersebut diantaranya untuk memenuhi kebutuhan domestik maupun non domestik. Kebutuhan domestik meliputi kebutuhan rumah tangga, mandi, minum, mck dan sebagainya, serta kebutuhan non domestik seperti pasar, industri, pertanian, tramsportasi dan sebagainya. Untuk memenuhi kebutuhan air bersih manusia bergantung dengan air tanah. Air tanah merupakan bagian dari siklus hidrologi yang dapat di temukan di bagian bawah permukaan tanah [34] Air tanah disimpan di dalam pori-pori tanah pada ruang pori antar butir, retakan, atau pada lorong pelarutan [6].

Menurut Balai Konservasi Air Tanah Kementrian ESDM (BKAT), penggunaanair tanah DKI Jakarta pada tahun 2015 adalah $60 \%$ dari total kebutuhan air bersih, dan 40\% menggunakan air PAM. Jumlah air tanah di konsumsi oleh penduduk DKI Jakarta pada tahun tersebut $496.356 .207 \mathrm{~m}^{3}$. Sedangkan penduduk DKI Jakarta pada tahun 2015 mencapai 10.177.924 jiwa (BPS, 2016). Hal ini setiap satu jiwa menggunakan $48,76 \mathrm{~m}^{3}$ air tanah tiap tahunnya. Penggunaan air tanah terus menerus dapat menimbulkan penurunantanahdi DKI Jakarta (Djaja, Raisetal.2004). Terjadi penurunan tanah di DKI Jakarta sebesar $0-12 \mathrm{~cm}$ tiap tahunnya pada periode 1996-2016 [9]

Masalah berikutnya dari penggunaan air tanah adalah buruknya kualitas baku mutu air. Berdasarkan BKAT tahun 2015, kondisi air tanah di DKI Jakarta pada lapisan akuifer bebas terdapat 16 dari 85 sumur yang dipantau memenuhi standar baku air dan 69 sumurpantau tidak memenuhi standar baku mutu air. Pada tahun 2018, sebanyak lima kelurahan di tiga kecamatan yang berbeda di Jakarta Barat yaitu kecamatan Kalideres, Kebon Jeruk, Taman Sari mengalami pencemaran berat (Dinas Lingkungan Hidup DKI Jakarta, 2019)(Gambar1.1). Menurut Dinas Lingkungan Hidup DKI Jakarta pada tahun 2019, air 
tanah memiliki indeks pencemaran berat apabila air mengandung air raksa,helium, zat padat dan zat kimia lainnya. Selain itu, terdapat kecamatan yang mengandung bakteri $e$ - coli pada air tanah yaitu kecamatan Palmerah [9]

Penggunaan air tanah perlu dilihat dari aspek fisika, maupun kimia untuk menentukan kualitas air yang dapat dikonsumsi oleh warga. Standar penggunaan air tanah tertuang dalam Peraturan Menteri Kesehatan nomer 492 tahun 2010 tentang persyaratan kualitas air minum. Air memegang penting dalam kehidupan, sehingga penting untuk mempelajari kualitas air tanah dengan menggunakan analisis hidrogeologi dan hidrokimia.

\section{METODE PENELITIAN}

Penelitian kualitas air tanah di Jakarta Barat berfokus pada akuifer bebas di perumahan padat penduduk. Penelitian dilakukan dengan dua jenis data yaitu data primer dan sekunder. Data primer yaitu data kedalaman air tanah, data analisis labortarium, dan data inti bor. Data sekunder meliputi data MAT dan kualitas air tanah pada tahun 2019-2020. Data sekunder penulis dapatkan melalui data yang dikeluarkan oleh Balai Konservasi Air Tanah (BKAT).

Secara umum penelitian dibagi menjadi empat tahap yaitu tahap persiapan, tahap pengumpulan data, tahap pengolahan data, dan tahap akhir. Tahap persiapan diawali dengan mengurus perijinan melakukan penelitian, pengajuan data sekunder ke Balai Konservasi Air Tanah DKI Jakarta (BKAT), serta mempersiapkan peralatan pengambilan sampel seperti EC TDS Meter, pH Meter, alat ukur kedalaman, alat tulis, dan sebagainya berhubungan dengan persiapan. Penulis juga melakukan persiapan piranti lunak seperti ARC GIS 10.6, Ms.Excel yang digunakan untuk mengolah data.

Selanjutnya adalah tahap pengumpulan data. Tahap pengumpulan data yaitu mengolah data-data yang didapatkan penulis seperti data kedalaman air tanah, data inti bor batuan, data pengukuran fisika dan kimia dilapangan, serta data analisis labortarium. Selanjutnya adalah tahap pengolahan data. Tahap pengolahan data bertujuan untuk mencari hubungan antara data yang telah diambil, melakukan pengambilan data di lapangan, membuat gambaran awal penelitian, melakukan persebaran kualitas air terhadap data-data yang didapatkan. Seluruh data diolah untuk mendapatkan keadaan sebenarnya mengenai kualitas air tanah di Jakarta Barat. Pemetaan kualitas air mengacu standar air bersih yang ditetapkan oleh pemerintah melalui Peraturan Menteri Kesehatan No 492 Tahun 2010.

Tahap akhir dari penelitian adalah untuk mendapatkan persebaran kualitas air tanah di Jakarta Barat menggunakan analisis hidrogeologi dan hidrokimia.

\section{HASIL DAN PEMBAHASAN}

1. Kondisi Hidrogeologi

Kondisi hidrogeologi wilayah penelitian berdasarkan pengukuran dilapangan pada bulan Maret tahun 2021, didapatkan dua keadaan mengenai pengukuran tersebut. Keadaan pertama yaitu daerah Tenggara dan Barat Daya memiliki sumur yang lebih dalam dibandingkan area sekitarnya. Kondisi ini terlihat pada sampel H3S2 yang memiliki kedalaman 9 mbmt, serta H5S4 dan H5S5 memiliki kedalaman 4 mbmt. Kondisi kedua yaitu bagian Utara dan tengah memiliki kedalaman sumur yang lebih dangkal. Keadaan tersebut menjadi pertimbangan untuk menentukan daerah luahan dan imbuhan.

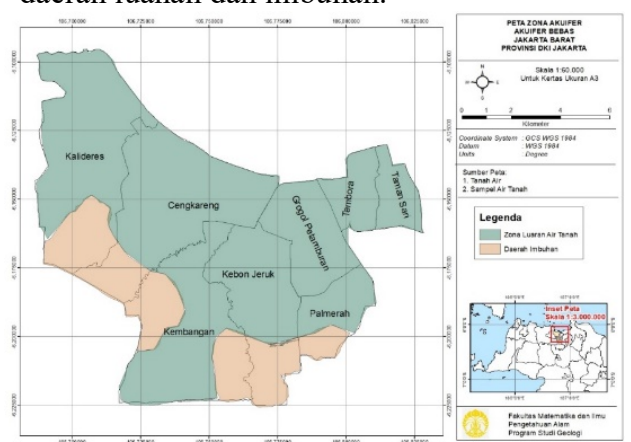

Gambar1. Peta Zona Akuifer Jakarta Barat

Daerah imbuhan terdapat pada kode sampel H3S2, H5S4, H5S5, dan H8S2. Keempat sampel terletak di Kelurahan Semanam, Palmerah, Srengseng, dan Kembangan Selatan. Selain itu diidentifikasikan sebagai daerah luahan. Sehingga, zona akuifer Jakarta Barat menjadi dua yaitu imbuhan dengan dinterpretasikan warna coklat,dan zona luahan diinterpretasikan dengan warna hijau. Daerah imbuhan terletak pada tiga kecamatan yaitu $\pm 25 \%$ Wilayah Kebon Jeruk, \pm $20 \%$ wilayah Kalideres, dan Kembangan, dan \pm 10\% Cengkareng dan Palmerah.

Daerah luahan terletak pada wilayah bagian Utara hingga Selatan (Gambar 1a). Wilayah tersebut mencakup kecamatan Taman Sari, Tembora, Grogol Petamburan, Palmerah, Kebon Jeruk, $\pm 90 \%$ wilayah Cengkareng, $\pm 80 \%$ wilayah Kembangan, dan $\pm 60 \%$ wilayah Kalideres. Sehingga dapat diinterpretasikan untuk menentukan peta zonasi akuifer bebas Jakarta Barat.

Pada pengukuran MAT tahun 2021, ketinggian MAT tertinggi dengan warna merah dengan kode sampel H8S3, dan H5S4 berada pada kelurahan Meruya Selatan, dan Palmerah. Kedua sampel tersebut terukur dengan ketinggian 17,2 mdpl, dan 14,5 mdpl. MAT terdalam dengan warna hijau tua dengan kode sampel H2S4 dan H2S5, masing-masing memiliki kedalaman -3,17 mdpl dan -2,02 mdpl. 


\section{Kondisi Hidrokimia}

Analisis pertama dalam hidrokimia adalah salinitas. Analisis salinitas menggunakan data labortarium. Sampel yang digunakan berjumlah dua belas titik sumur yang diambil melalui sampel air tanah warga di Jakarta Barat (Gambar 3). Acuan klasifikasi salinitas merujuk kepada Todd (1980).

Peta salinitas menunjukkan dengan warna hijau dengan persentase $\pm 60 \%$ wilayah penelitian memiliki klasifikasi air tawar, sedangkan warna kuning dengan persentase $\pm 40 \%$ adalah air payau (Gambar 2). Berdasarkan peta batas-batas salinitas terletak pada kode sampel H4S2 di Grogol Petamburan, H4S\% di Cengkareng, dan H8S2 di Kembangan. Batas-batas tersebut membagi menjadi dua wilayah yaitu disebelah utara dan selatan. Wilayah utara memiliki salinitas yang lebih tinggi dengan rentang persentil $5-17 \%$, sedangkan wilayah selatan dibawah $5 \%$.

Analisis berikutnya adalah jenis air tanah menggunakan total padatan terlarut pada air tanah atau total disolved solid (TDS). Satuan TDS menggunakan $\mu \mathrm{S} / \mathrm{cm}$. Data didapatkan melalui pengukuran langsung di sumur warga Jakarta Barat. Parameter TDS yang digunakan merujuk kepada PAHIAA (1986). Berdasarkan persebarannya, air peralihan dan air payau lebih banyak dijumpai pada wilayah Jakarta Barat bagian Utara yang memiliki posisi mendekati pantai Jakarta Utara, dibandingkan wilayah Jakarta Barat bagian Selatan memiliki jenis air tawar (Gambar 3).

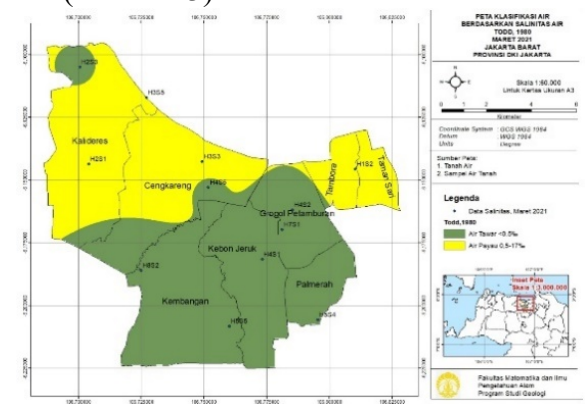

Gambar 2. Salinitas Air Tanah di Jakarta Barat

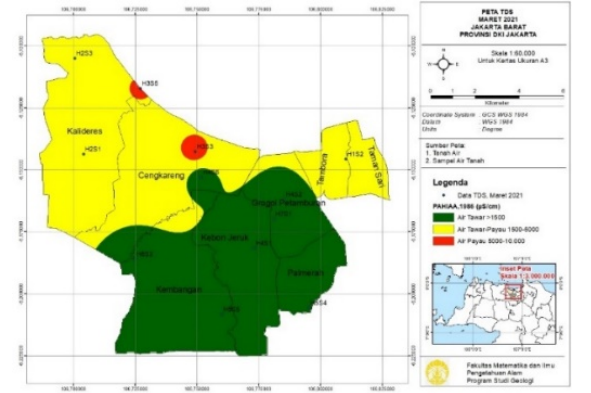

Gambar 3. Peta Jenis Air Tanah Daerah Penelitian

Hal ini disebabkan oleh beberapa beberapa kemungkinan, yang pertama adalah pengaruh topografi
Jakarta Barat bagian Utara lebih rendah dibandingkan Selatan sehingga mungkin dapat terjadi intrusi air laut, serta sampel H2S5 terletak pada elevasi -2mdpl. Kemungkinan kedua adalah faktor batuan asal yang merupakan secara geologi regional adalah endapan pematang pantai [36]. Sehingga air tanah terpengaruh oleh batuan asal.

Berikutnya adalah membahas tingkat keasaman pada air tanah.Tingkat keasaman menggunakan pengukuran $\mathrm{pH}$ untuk membuat dugaan awal kandungan asam dan basa pada air tanah sebelum melihat perbandingan anion dan kation melalui analisis labortarium.

Berdasarkan persebaran $\mathrm{pH}$, penulis membagi menjadi 5 kelas rentang $\mathrm{pH}$, dengan rincian dua kelas tidak memenuhi dan tiga kelas memenuhi standar kualitas air untuk minum menurut Permenkes No.492 tahun 2010. Kelas pertama yaitu warna merah digunakan untuk air memiliki $\mathrm{pH}$ rendah yaitu dibawah 6, terdapat pada kode sampel H7S1 yang terletak di Tanjung Duren Utara. Kelas kedua berwarna oranye digunakan untuk air tanah dengan nilai $\mathrm{pH}$ mendekati standar air minum yaitu $\mathrm{pH}$ 6-6,5. Kelas ini terdapat pada kode sampel H5S4 di kelurahan Palmerah dan H5S5 di kelurahan Srengseng. Kelas ketiga sudah memenuhi standar Permenkes No. 492 tahun 2010 dengan $\mathrm{pH}$ mendekati netral yaitu 6,5-7. Rentang kelas ini terdapat pada kecamatan kembangan dengan kode sampel H8S2.

Kelas keempat disimbolkan dengan warna hijau, serta mendominasi di Utara wilayah penelitian. Kelas ini dengan $\mathrm{pH}$ netral yaitu 7-7,5 dengan kode sampel H1S2, H2S1, H2S3, H3S3, H3S5, dan H4S1, masing-masing terletak di kelurahan Roa Melaka, Pegadungan, Kamal, Kapuk, dan Tegal Alur. Kelas terakhir adalah kelas kelima dengan $\mathrm{pH}$ tertinggi mendekati basalemah yaitu 7,5-8 dengan disimbolkan warna biru. Pada kelas ini terdapat pada kode sampel H4S2, dan H4S6, masing-masing terletak di Jelambar, dan Kedungkaliangke.

Berikutnya setelah melihat $\mathrm{pH}$ pada air tanah yaitu tingkat Charge Balance Eror ( $C B E$ ). Analisis Charge Balance Eror digunakan untuk mengetahui kualitas data [15].CBE dilakukan untuk menganalisis kedua belas sampel data air tanah yang tersebar pada air tanah warga Jakarta Barat. Hasil CBE tertera pada tabel 1 . 
Jurnal Inovasi Pendidikan dan Sains

Vol. 2 No. 2, Agustus $2021: 38-54$

Tabel 1. Perhitungan Charge Balance Eror

\begin{tabular}{|c|c|c|c|c|c|c|c|c|}
\hline \multirow{3}{*}{$\begin{array}{c}\text { Kode } \\
\text { Sampel }\end{array}$} & \multicolumn{3}{|c|}{ Kation } & \multicolumn{3}{|c|}{ Anion } & \multirow{3}{*}{$\begin{array}{l}\text { Hasil } \\
\text { CBE }(\%)\end{array}$} & \multirow{3}{*}{ Penilaian } \\
\hline & $\mathrm{Ca}$ & Mg & $\mathrm{Na}$ & SO4 & Cl & $\mathrm{HCO} 3$ & & \\
\hline & $(\mathbf{m e q} / \mathbf{L})$ & $($ meq/L) & $($ (meq/L) & $($ (meq/L) & $($ (meq/L) & $(m e q / L)$ & & \\
\hline HIS2 & 8,25 & 3,675 & 10,26087 & 2,3125 & 22,48571 & 6,114754 & -14,7456 & $\begin{array}{c}\text { Tidak } \\
\text { Diterima }\end{array}$ \\
\hline $\mathrm{H} 2 \mathrm{~S} 1$ & 5 & 4,675 & 12,21739 & 18,5625 & 8,657143 & 9,557377 & $-24,7108$ & $\begin{array}{c}\text { Tidak } \\
\text { Diterima }\end{array}$ \\
\hline $\mathrm{H} 2 \mathrm{~S} 3$ & 5,4 & 5,583333 & 9,73913 & 4,333333 & 12,4 & 14,06557 & $-18,4262$ & $\begin{array}{c}\text { Tidak } \\
\text { Diterima }\end{array}$ \\
\hline $\mathrm{H} 3 \mathrm{~S} 3$ & 2,9 & 4,016667 & 17,95652 & 6,75 & 30,22857 & 8,754098 & $-28,5955$ & $\begin{array}{c}\text { Tidak } \\
\text { Diterima }\end{array}$ \\
\hline H3S5 & 9,85 & 5,3 & 16,43478 & 8,166667 & 32,22857 & 6,901639 & -18,5696 & $\begin{array}{c}\text { Tidak } \\
\text { Diterima }\end{array}$ \\
\hline $\mathrm{H} 4 \mathrm{~S} 1$ & 5,3 & 0,8175 & 1,478261 & 0,8125 & 0,314286 & 8,229508 & $-8,30488$ & $\begin{array}{c}\text { Tidak } \\
\text { Diterima }\end{array}$ \\
\hline $\mathrm{H} 4 \mathrm{~S} 2$ & 2,9 & 0,7075 & 3 & 1,208333 & 2,371429 & 5,180328 & $-12,402$ & $\begin{array}{c}\text { Tidak } \\
\text { Diterima }\end{array}$ \\
\hline $\mathrm{H} 4 \mathrm{~S} 6$ & 2,2 & 0,313333 & 0,565217 & 0,75 & 0,4 & 2,655738 & $-7,65985$ & $\begin{array}{c}\text { Tidak } \\
\text { Diterima }\end{array}$ \\
\hline H5S4 & 1,15 & 0,439167 & 0,73913 & 0,979167 & 2,371429 & 0,918033 & $-27,2658$ & $\begin{array}{c}\text { Tidak } \\
\text { Diterima }\end{array}$ \\
\hline H5S5 & 2,6 & 0,815 & 0,695652 & 0,458333 & 2,142857 & 0,983607 & 7,281284 & $\begin{array}{c}\text { Tidak } \\
\text { Diterima }\end{array}$ \\
\hline H7S1 & 1,7 & 0,3275 & 0,521739 & 2,375 & 0,428571 & 0,065574 & -3,98014 & Diterima \\
\hline H8S2 & 2,5 & 1,391667 & 0,608696 & 1,666667 & 1,6 & 3,131148 & $-16,8362$ & $\begin{array}{c}\text { Tidak } \\
\text { Diterima }\end{array}$ \\
\hline
\end{tabular}
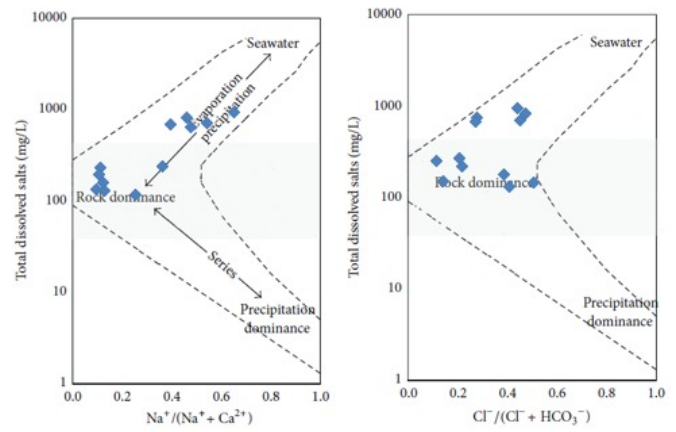

Gambar 4. Diagram Gibbs

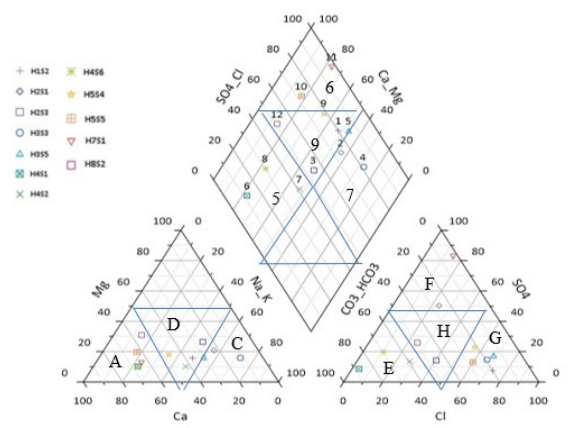

Gambar 5. Diagram Jajargenjang adan Segitiga Kation dan Anion atrilinear Piper Air Tanah

Berdasarkan perhitungan CBE, didapatkan rentang nilai-3,9\% - 7\%. Toleransi CBE yang dapat diterima memiliki nilai dibawah $5 \%$ dan diatas $-5 \%$. Sehingga, hanya satu data yang memenuhi kriteria yaitu sampel H7S1, dan sisanya tidak memiliki kualitas data yang baik [15]. Ada beberapa faktor data mempengaruhi kualitas data yang dihasilkan. Faktor tersebut diantaranya adalah kesalahan manusia seperti penimbangan larutan yang tidak sesuai oleh laboran sehingga dapat terjadi kesalahan pembacaan konsentrasi yang berkurang atau berlebihan. Faktor kedua adalah tercemarnya air saat pengambilan sampel mengingat sumur terdapat di dalam toilet mck rumah padat penduduk bisa jadi ada faktor pengotor melalui
ISSN 2721-9119 (Online)

aktivitas mandi cuci kaktus (mck). Faktor ketiga adalah adanya ion elemen utama yang tidak terbaca saat pengukuran sehingga perlu dianalisis lebih lanjut mengingat data dominan adalah anion sehingga mengindikasikan adanya kation yang belum terbaca. Pertimbangannya adalah daerah penelitian merupakan perumahan padat penduduk yang dekat dengan area industri seperti di kelurahan Pegadungan, Durikepa, Kapuk, dan Cengkarengsehingga mengindikasikan adanya pencemaran logam berat yang tidak terbaca didalam data kimia penelitian dan diperlukan analisis lebih lanjut mengenai kandungan logam berat seperti timbal, kobalt, dan sebaginya.

Selanjutnya adalah kontrol kandungan air tanah. Kontrol kandungan air tanah melalui analisis komposisi air tanah menggunakan nilai TDS (total dissolved solid) dengan nilai rasio dari kation utama air tanah yaitu $\mathrm{Na}^{+}, \mathrm{K}^{+}$dan $\mathrm{Ca}^{2+}$ dan anion utama yaitu $\mathrm{Cl}^{-}$ dan $\mathrm{HCO}^{3}$ di dalam diagram Gibs.

Dari hasil data rasio kation dan anion yang telah di plot pada Diagram Gibbs air tanah, dapat diinterpretasikan bahwa wilayah penelitian menunjukkan dominan pelapukan batuan (rock dominance)(Gambar 3a) dengan 7 dari 12 sampel. Sampel tersebut terdapat pada nomer sampel H4S1H8S2 dengan nilai TDS yang rendah $<1000 \mathrm{mg} / 1$ yang umumnya terletak di tengah atau Selatan jakarta Barat. Wilayah penelitian yang dekat dengan Jakarta Utara yaitu H1S2-H3S5 memiliki nilai TDS $>1000 \mathrm{mg} / \mathrm{l}$.

Berdasarkan Diagram Gibbs, wilayah penelitian di pengaruhi oleh pelapukan batuan melalui 7 dari 12 sampel yang diteliti. Sedangkan 5 dari 12 sampel memiliki nilai TDS $>1000 \mathrm{mg} / 1$ dan rasio kation dan anion $<1$ [17]. Pada diagram Gibbs terletak di tengah antara pelapukan batuan dengan intrusi air laut,. Namun, posisi 5 dari 12 sampel tersebut lebih mendekati pelapukan batuan.

Analisis berikutnya adalah fasies air tanah. Analisis fasies air tanah menggunakan nilai kation dan anion utama pada air tanah yaitu $\mathrm{Na}^{+}, \mathrm{K}^{+}, \mathrm{Ca}^{2+}$ dan $\mathrm{Mg}^{2+}$ dan anion utama yaitu $\mathrm{Cl}^{-}, \mathrm{HCO}^{3-}$ dan $\mathrm{SO}_{4}{ }^{2-}$ serta menggunakan diagram Piper. Masing-masing molekul dikonversi satuannya dari miligram per liter $(\mathrm{mg} / \mathrm{l})$ menjadi persen miliequivalen per liter $(\% \mathrm{meq} / 1)$ pada dua belas sampel air tanah yang warga Jakarta yang tersebar di Jakarta Barat.

Analisis pertama mengenai Diagram Piper jajar genjang. Pada diagram tersebut terdapat dua analisis yang dapat dibahas. Pertama padalah melihat tipe fasies air tanah berdasarkan kation dan anion (Gambar7). Berdasarkan analisis Diagram jajar genjang Trilinear Piper (Gambar 3b) didapatkan dominan klasifikasi 9 dengan 4 dari 12 sampel air tanah tipe campuran dengan kandungan kation dan anion seimbang serta tidakmelebihi $>50 \%$ (Walton, 1970).

Analisis kedua dalam diagram jajar genjang adalah melihat dominasi kation dan anion untuk melihat perbedaan asam dan basanya . Pada grafik sebelah kiri menggambarkan air tanah Jakarta Barat 
masuk ke dalam klasifikasi 1 dimana unsur alkali tanah melebihi unsur. Kondisi ini disebut sebagai air sadah (Philip Kristanto, 2004). Pada grafik sebelah kanan menggambarkan kondisi anion air tanah di Jakarta Barat. Pada grafik tersebut terdapat 9 dari 12 sampel menunjukkan asam kuat $\left(\mathrm{SO}_{4}{ }^{2-}+\mathrm{Cl}^{-}\right)$lebih dominan dibandingkan asam lemah $\left(\mathrm{CO}_{3}{ }^{2-}+\mathrm{HCO}^{3-}\right.$.Terakhir dalam diagram Piper adalah diagram segitiga untuk melihat dominansi unsur didalam fasies air tanah Pada diagram segitiga memiliki kation dominan pada kelompok A yaitu kalsium dengan 5 dari 12 sampel. Berikutnya pada anion dengan dominan tipe G. Tipe $G$ merupakan tipe anion air tanah dengan kelimpahan dominan klorida.

Selanjutnya adalah hubungan antar ion dengan menggunakan analisis Diagram Durov. Berdasarkan Diagram Durov, dapat diinterpretasikan bahwa mayoritas ion terletak pada Tipe 5. Tipe 5 dicirikan dengan tidak ada ion dominan antara anion dan kation, karena air telah tercampur rata.Posisi kedua adalah Tipe 2. Tipe ini memiliki memiliki ion dominan $\mathrm{Ca}$, dan $\mathrm{Mg}$. Kelimpahan unsur tersebut menandakan air tanah berasosiasi dengan dolomit serta ion $\mathrm{Mg}$ yang melimpah (Gambar 4).

3. Hubungan Hidrogeologi dan Hidrokimia

Melalui petrografi dan XRD yang dilakukan oleh Listyani (2016) bahwa batuan memiliki mineral dolomit [23]. Menurut Bowen (1986) Dolomit berasosiasi dengan $\mathrm{Fe}^{2+}, \mathrm{Fe}^{3+}, \mathrm{Ca}^{2+}, \mathrm{Mg}^{2+}, \mathrm{Cl}^{-}$, dan $\mathrm{F}$. Artinya air tanah pada daerah penelitian terpengaruh oleh kondisi batuan bawah tanah. Selain itu, kondisi asin pada Utara Jakarta Barat dipengaruhi oleh mineral hornblend yang berasosiasi dengan air tanah.

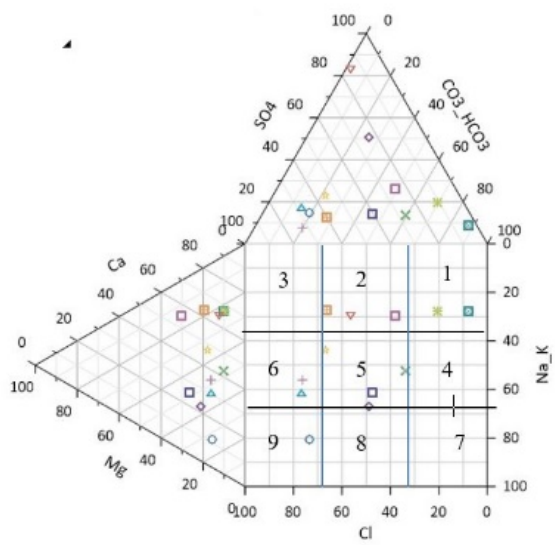

Gambar 6. Diagram Durov Hubungan Antar

4. Studi Kualitas air Tanah

a. Peta Tahun 2018

Peta Kualitas Air Tanah tahun 2018 merupakan peta berdasarkan data BKAT menggunakan 17 titik data (Gambar 5a). Didalam zonasi peta kualitas air penulis membagi menjadi tiga kategori berdasarkan warna yaitu hijau, kuning, dan merah. Kategori warna Hijau untuk daerah yang memenuhi parameter fisika dan kimia kualitas air baku untuk minum menurut standar Permenkes No. 492 tahun 2010. Sedangkan kategori kuning untuk air yang tidak memenuhi parameter fisika atau kimia. Terakhir adalah kategori warna merah untuk air yang tidak memenuhi parameter fisika dan kimia.

Berdasarkan peta kualitas air tanah tahun 2018, Kecamatan Palmerah, dan Kebon Jeruk memenuhi standar kualitas air baku untuk minum. Sedangkan daerah Kembangan sebelah Utara, dan Grogol Petamburan tidak memenuhi parameter Fisika dengan nilai TDS melebihi 500. Sedangkan zona merah pada peta dengan $\pm 75 \%$ wilayah penelitian tidak memenuhi parameter fisika dan kimia. Area tersebut memiliki nilai TDS lebih dari 500 dan unsur kimia yang bervariasi tiap sampelnya dengan ditemukan kelebihan unsur Mangan, Natrium dan Klorida.

b. Kualitas Air Tanah 2019

Peta Kualitas Air Tanah tahun 2019 merupakan peta berdasarkan data BKAT menggunakan 14 titik data. Pengukuran tahun 2019 merupakan zona kuning dengan 40\% area. Sedangkan zona merah dengan 8 dari 14 sampel yang di ukur tidak memenuhi parameter fisika dan kimia dengan $45 \%$ area.

c. Kualitas Air Tanah 2020

Periode musim hujan bulan Maret tahun 2020, BKAT melakukan pengukuran kualitas air tanah di Jakarta Barat. Pada periode ini, penulis mendapatkan 12 titik data dari BKAT. Zona hijau terlihat pada pengukuran di palmerah dengan kode 2, dan Masjid Al Ikhlas di Kapuk dengan kode data nomer 10 memiliki kualitas air tanah yang memenuhi standar air baku untuk minum. Terjadi perbedaan di Kecamatan Kebon Jeruk menjadi zona kuning. Perubahan tersebut akibat menurunya $\mathrm{pH}$ menjadi 6,4 dari standar ketetapan Permenkes nomer 492 tahun 2010 adalah 6,5. Daerah Joglo, dan Roa Melaka (Gambar 7).

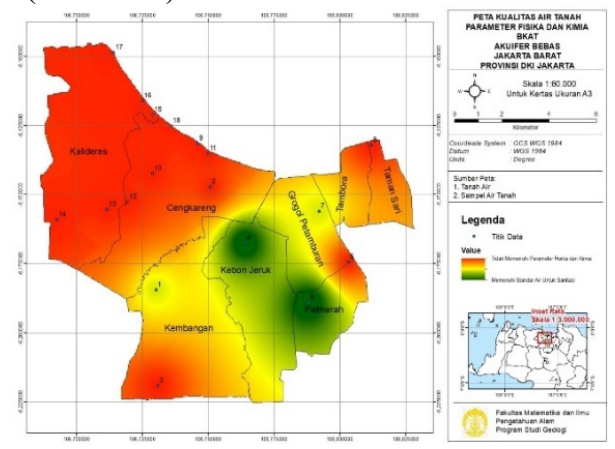

Gambar 7. Peta Kualitas Air Tanah tahun 2018 
Peta kualitas air tanah musim kemarau bulan September tahun 2020, terdapat tiga zona warna yaitu hijau, kuning dan merah berdasarkan tingkat pencemarannya (Gambar 18). Pada peta ini terlihat daerah Kebon Jeruk mengalami perubahan zona dari kuning saat musim hujan bulan Maret tahun 2020, dan berubah menjadi hijau pada saat kemarau bulan Agustus tahun 2020. Perubahan wilayah Kebon Jeruk terpantau melalui peningkatan pH dari 6,4 menjadi 7,29. Dapat terlihat dari kasus ini bahwa hujan di Jakarta cenderung asam sehingga dapat menurunkan $\mathrm{pH}$, adapun saat kemarau lebih dominan pengaruh lapisan batuan di bawah permukaan. Air tanah layak konsumsi berada di Kelurahan Joglo Kecamatan Kembangan dengan kode titik 11, dan Kebon Jeruk dengan kode 14. Berikutnya sedikit tidak layak konsumsi melalui zona kuning karena tidak memenuhi parameter Fisika terdapat di Kembangan dengan kode titik 10 dan palmerah dengan kode titik 12 . Air tidak layak konsumsi pada zona merah mendominasi wilayah penelitian dengan $\pm 60 \%$ dengan total 7 kode titik yang mayoritas di bagian Utara Jakarta Barat (Gambar 8).

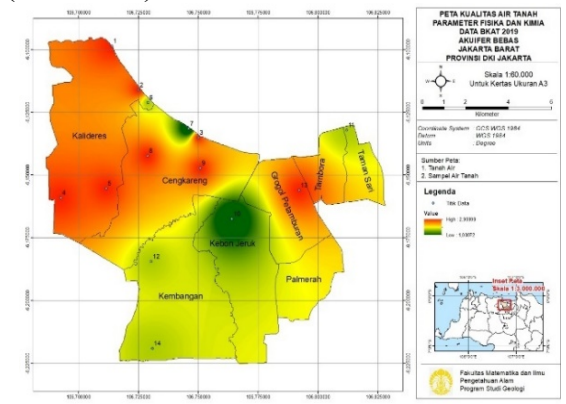

Gambar 8. Peta Kualitas Air Tanah tahun 2019

d. Kualitas air tanah tahun 2021

Kualitas air tanah tahun 2021, penulis menggunakan data sumur warga dengan jenis akuifer bebas yang berada pada perumahan padat penduduk, sehingga tidak melakukan pengukuran pada area publik seperti yang BKAT lakukan. Namun, terdapat beberapa titik sampel seperti di Kelurahan Roa Melaka dengan kode H1S2, Kelurahan Tegal Alur dengan kode H3S5, yang dapat dibandingkan dengan data BKAT (Gambar 6c).

Zona pertama adalah warna hijau dan hanya terletak di Kelurahan Kedaungkaliangke yang memenuhi kualitas air baku untuk minum. Sedangkan zona kedua yaitu warna kuning, sebagai zona kuning. Kategori kuning untuk sampel yang tidak memenuhi pada salah satu parameter seperti kode sampel H8S2 yang terletak di Kelurahan Kembangan Selatan dengan kandungan ion Mangan melebihi standar yaitu 0,46 .
Kemudian H5S4, dan H5S5, yang masingmasing terletak di Kelurahan Palmerah, dan kelurahan Srengseng tidak memenuhi standar nilai $\mathrm{pH}$ air yaitu 6,3 dan 6,2 . Zona kuning mendominasi bagian Selatan wilayah penelitian dengan meliputi Kecamatan Palmerah, Kembangan, 30\% Kapuk, dan 20\% Grogol Petamburan.

Zona terakhir yaitu zona merah, terdapat pada bagian Utara wilayah penelitian. Zona merah tidak memenuhi parameter fisika dan zona merah terlihat pada kode sampel H1S2 yang terletak di kelurahan Roa Melaka memiliki TDS lebih dari 500 yaitu 1959, nilai ion Natrium lebih dari standar yaitu 236 $\mathrm{mg} / \mathrm{L}$, serta Klorida yang tinggi yaitu 787 $\mathrm{mg} / \mathrm{L}$. Kelurahan Roa Melaka terpantau dari data BKAT dan data penulis keduanya tidak memenuhi standar parameter air baku untuk minum. Sedangkan kelurahan Tegal Alur sedikit berbeda perkembangannya, pada tahun 2018-2019 merupakan zona merah, sedangkan tahun 2020 musim penghujan berubah menjadi zona kuning karena menurunnya ion Amonium dan Mangan.

Kondisi tidak layak konsumsi, dengan air memiliki kandungan besi yang melebihi standar dijumpai pada H4S1 dan H4S2 yang terletak di kelurahan Duri Kepa dan Jelambar. Kedua kode sampel memiliki kandungan besi 0,4 mg/L dan 1,65 mg/L. Beberapa sampel memiliki kandungan mangan yang melebihi batas yang tinggi yaitu $\mathrm{H} 2 \mathrm{~S} 1, \mathrm{H} 3 \mathrm{~S} 3$, dan H4S1. Ketiga kode sampel terletak di Kelurahan Pegadungan, Kapuk, dan Duri Kepa. Masing-masing sampel memiliki kandungan Mangan 0,88 mg/L, 0,74 mg/L, dan $2,74 \mathrm{mg} / \mathrm{L}$.

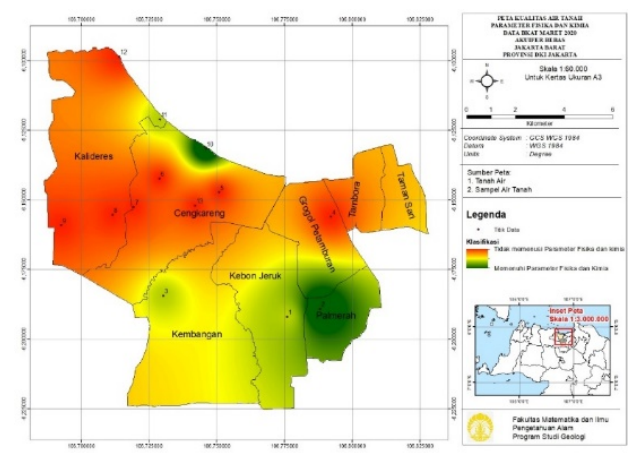

Gambar 9. (a) Peta Kualitas Air Tanah Tahun 2020 Musim Kemarau 
Jurnal Inovasi Pendidikan dan Sains

Vol. 2 No. 2, Agustus $2021: 38-54$

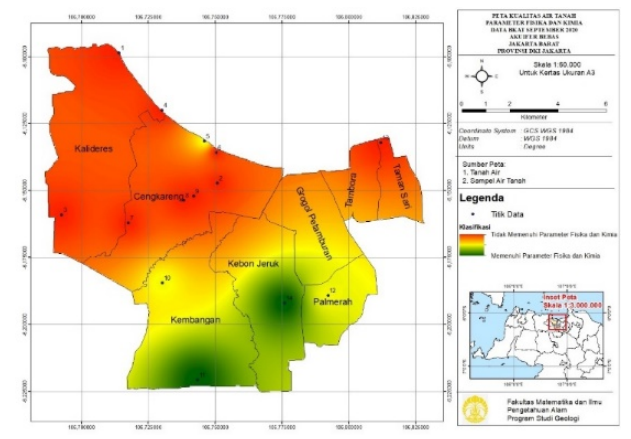

Gambar 9. (b) Peta Kualitas Air Tanah Tahun 2020 Musim hujan

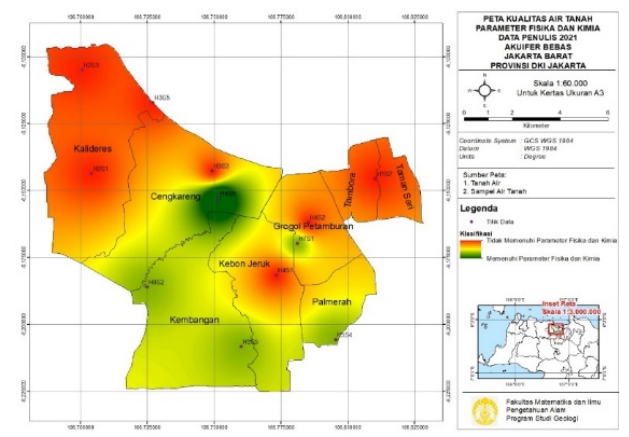

Gambar 9 (c) Peta Kualitas Air Tahun 2021

Setelah membedah zonasi pencemaran, berikutnya adalah fasies berdasarkan gambar 4.51 wilayah Jakarta Barat memiliki beragam fasies kimia. Parameter TDS secara umum mebgai wilayah penelitian menjadi dua, area Utara Jakarta Barat memiliki TDS yang lebih tinggi dibandingkan Selatan. Wilayah Utara yaitu sampel hari pertama hingga hari ketiga memiliki TDS diatas 500ppm, sedangkan hari keempat hingga harikedelapan memiliki nilai TDS dibawah 500 ppm.

Parameter berikutnya yaitu $\mathrm{pH}$ sebagai indikator asam dan basa air membagi menjadi tiga yaitu $\mathrm{pH}$ tinggi $8, \mathrm{pH}$ netral 7-8, dan asam dibawah 7 . $\mathrm{pH}$ tertinggi terletak di wilayah tengah penelitian yaitu H4S2, dan H4S6 yang terletak di Jelambar, Kecamatan Grogol Petamburan dan Kedaungkaliangke Kecamatan Cengkareng. Berikutnya adalah $\mathrm{pH}$ netral dengan rentang 7-8, terdapat di Utara Jakarta Barat, dengan kode sampel H1S2, H2S1, H2S3, H3S3, H3S5, dan H4S1. Terakhir adalah wilayah Selatan dengan $\mathrm{pH}$ asam dibawah 7 dengan nilai 4,4-6,6. Wilayah Selatan dengan kode sampel H5S4, H5S5, H7S1, dan H8S2.

Dapat disimpulkan melihat trend ion yang ada wilayah Utara cenderung lebih netral $\mathrm{pH}$ airnya karena memiliki jumlah perbandingan ion anion dan kation yang relatif lebih seimbang. Sedangkan pada wilayah Selatan memiliki $\mathrm{pH}$ yang relatif lebih asam karena biarpun kandungan anion maupun kation tidak tinggi menurut standar Permenkes No. 492 tahun 2010, tetapi perbandingan jumlah ion lebih banyak anion. Untuk wilayah tengah dengan $\mathrm{pH} 8$ memiliki jumlah kation yang lebih tinggi daripada anionnya, yaitu kesadahan

\section{ISSN 2721-9119 (Online)}

dan bikarbonat yang tinggi. Kusus untuk kode sampel H7S1 yang terletak di Tanjung Duren Utara memiliki nilai $\mathrm{pH}$ yang sangat rendah yaitu 4,4 . Ada beberapa hal yang mempengaruhi rendahnya $\mathrm{pH}$ diantaranya adalah air hujan, dekomposisi material organik (Barus, 2004). Selain itu, asam kuat lebih dominan dibandingkan basa kuat dan lemahnya.

\section{KESIMPULAN}

Berdasarkan penelitian dan analisis yang telah dilakukan penulis didapatkan beberapa kesimpulan, yaitu:

1. Kondisi Hidrogeologi Jakarta Barat yaitu daerah imbuhan berada di Barat Daya dan Tenggara daerah penelitian, dan luahan adalah Utara Jakarta Barat. Berdasarkan perubahan ketinggian rata-rata MAT dalam mdpl dari tahun 2018-2021 bervariasi di tiap kelurahannya dari penurunan hingga penambahan ketinggian MAT. Penurunan terbesar terjadi di Kelurahan Tegal Alur yaitu 0,51 $\mathrm{mdpl} /$ tahun, dan kenaikan air tanah tertinggi terjadi di Kalideres yaitu 3,51 mdpl/tahun.

2. Kondisi Hidrokimia daerah penelitian berdasarkan salinitas terdapat dua jenis air yaitu air tawar yang terletak di Selatan Jakarta Barat dan air payau di Utara Jakarta Barat. Sedangkan jenis air dengan parameter TDS yaitu bagian Utara memiliki jenis air payau dan air payau tawar, serta bagian Selatan memiliki jenis air tawar. Berdasarkan kontrol kandungan air tanah melalui diagram Gibs diketahui bahwa air tanah dipengaruhi oleh jenis litologi batuannya yang mempengaruhi unsur ion air tanah. Beradasrkan hubungan antar ion berdasarkan Diagram Durov air tanah dari sampel air yang di uji kandungannya memiliki tipe campuran dengan dominan sampel bertipe 5 dengan 4 dari 12 sampel tidak ada ion dominan antara anion dan kation, karena air telah tercampur rata, diiukuti tipe 2 dengan jumlah yang tidak jauh berbeda dengan tipe 5 dengan 3 dari 12 yaitu ion dominan $\mathrm{Ca}$, dan $\mathrm{Mg}$.

3. Kondisi hidrogeologi dan hidrokimia daerah penelitian dipengaruhi dengan kondisi litologi batuan. Kondisi tersebut teramati melalui sayatan tipis dari data inti batuan terdapat mineral hornblende yang berasosiasi $\mathrm{Fe}^{2+}, \mathrm{Fe}^{3+}, \mathrm{Ca}^{2+}$, $\mathrm{Mg}^{2+}, \mathrm{Cl}^{-}$, dan F. Kondisi tersebut mempengaruhi rasa asin pada air tanah di Utara Jakarta Barat.

4. Kualitas air tanah tahun 2021 pada perumahan padat penduduk di Jakarta Barat berdasarkan standar Permenkes nomer 492 tahun 2010, terdapat tiga zona kualitas yaitu hijau, kuning, dan merah. Zona hijau yaitu air tanah yang memenuhi parameter fisika dan kimia, zona kuning yang tidak memenuhi salah satu dari parameter tersebut, dan zona merah tidak memenuhi parameter fisika dan kimia. Zona hijau terdapat pada Kelurahan Kedaung Kaliangke, Kecamatan Cengkareng. Sedangkan 
zona kuning mendominasi bagian Selatan penelitian seperti Kecamatan Kembangan, Palmerah, sebagian Kebon Jeruk, dan sebagian Cengkareng. Sedangkan zona merah terletak pada wilayah Jakarta Barat seperti Kecamatan Tambora, Kalideres, dan sebagian Cengkareng.

\section{DAFTAR PUSTAKA}

[1] Ashriyanti, Hidanafie. (2011). Kajian Kerentanan Pada Wilayah Terintrusi Air Laut. (Tesis). Program Studi Geografi. Universitas Indonesia

[2] Assegaf, A. 1998. Hidrodinamika Airtanah Alamiah Cekungan Jakarta. (Tesis), Program Studi T. Geologi, Program Pasca Sarjana.

[3] Assegaf, A., Hendarmawan, Hutasoit, L.M., Hutabarat, J. (2017). Salinitas Airtanah Akifer Tidak Tertekan Kedalaman 0 - 20 m Daerah Kalideres - Cengkareng, Jakarta Barat. Jurnal RISET Geologi dan Pertambangan. Vol.27, No.1, Juni 2017,15 - 25. Pusat Penelitian Geoteknologi Lembaga Ilmu Pengetahuan Indonesia.

[4] Indeks Pencemaran DKI Jakarta, Badan Pusat Statistik, (2016).

[5] Banks, D., Frengstad, B., (2006). Evolution of groundwater chemical composition by plagioclasehydrolysis in Norwegian anorthosites. Geochem. Cosmochim. Acta 70,1337-1355.

[6] Cahyadi, A., dan Hidayat, W. (2017). Analisis Karakteristik Hidrogeokimia Air Tanah di Pulau Korang Panggang, Kepulauan Seribu, DKI Jakarta. Jurnal Geografi Vol 9 No.2 (99-108).

[7] Chow, VT, (1988).Applied Hydrology. New York: Mc-Graw-Hill Company

[8] Çinar, Ö., \& Merdun, H. (2009). Application of an unsupervised artificial neural network technique to multivariant surface water quality data. Ecological Research, 24(1), 163-173. doi: 10.1007/s 11284-008-0495-z.

[9] Dayanti, M.P. (2017). Kualitas Air Tanah di Kecamatan Palmerah Jakarta Barat ditinjau dari pola sebaran Escherichia coli. Jakarta: Universitas Trisakti.

[10] Djaja,R.,etal.(2004).LandsubsidenceofJakartame tropolitanarea.Proceedingsofthe 3rd FIG Regional Conference for Asia and thePacific.

[11] Fachri, M., Djuhaeni, Hutasoit, L.M., dan Ramdhan, A.M., (2002). Stratigrafi dan hidrostratigrafi Cekungan Airtanah Jakarta. Bulletin Geologi, Vol. 34, No. 2, hal 169 - 190

[12] Fatoni, Muhammad, dkk. (2018). Studi Agihan Salinitas Air Tanah Dangkal di Kecamatan Puring Kabupaten Kebumen Tahun 2016. Jurnal GeoEco. Vol.4.No.1. Januari 2018. ISSN. 24600768

[13] Fetter, C.W. (2014). Applied Hydrogeology, fourth edition. USA : Pearson

[14] Firdaus, Bakri, H., dan Raul, J. (2018).
Penentuan Lapisan Akuifer Berdasarkan Hasil InterpretasiGeolistrik(TahananJenis)diDesaNon ongProvinsiSulawesiTengah. Jurnal Geomine, Vol. 6, No. 2: Agustus2018.

[15] Freeze and Cherry (1979). Ground Water. New Jearsy : Prentice-Hall, Inc

[16] Ge, S., Gorelick, S. M. (2014). Encyclopedia of Atmospheric Science (Second Edition). USA: Academic Pres

[17] Geriesh, M., (1994). Hydrogeological and hydrochemical evaluation of groundwater resources in the Suez Canal region. Egypt. $\mathrm{PhD}$ Thesis. Suez Canal University.

[18] Gibbs, J.R., (1970). Mechanisms controlling world water chemistry. Science (80-. ) 170, 1088-1090.

[19] Hiscock, K.M. and Bense, V.F. (2014). Hydrogeology: Principles and Practice, Second Edition. Chichester: John Wiley and Sons Ltd.

[20] Hutabarat, L.E. (2017). Studi Penurunan Air Tanah (Land Subsidence) Akibat Pengambilan Air Tanah Berlebihan di DKI Jakarta. Jakarta: UKI Press

[21] Kementrian PUPR. (2017). Modul Geologi dan Hidrogeologi Pelatihan dan Pencernaan Air Tanah. Pusat Pendidikan dan Pelatihan Sumber Daya Air dan Konstruksi: Jakarta.

[22] Listiawan, Yudhi, (2015). Kajian Potensi Intrusi Air Laut Berdasarkan Karakteristik Hidrokimia Airtanah Di Daerah Karangwuni Kecamatan Wates Kabupaten Kulon Progo Provinsi D.I Yogyakarta. Seminar Nasional ke-II FTG Universitas Padjadjaran.

[23] Listyani, T.R.A, (2016).Rock's Mineral Control on Groundwater Quality in Jakarta Groundwater Basin.Prosiding Seminar Nasional XI "Rekayasa Teknologi Industri dan Informasi 2016, Yogyakarta: Sekolah Tinggi Teknologi Nasional

[24] Lubis, R.F., Sakura, Y., and Delinom, R. (2008). Groundwater Recharge and Discharge Processes in the Jakarta Groundwater Basin, Indonesia. Springer. Hydrogeology Journal 16: 927-938

[25] Lloyd. J. W., and Heathcote J. A. (1985). Natural inorganic hydrochemistry in relation to groundwater - An introduction:Clarrendon Press, England: Oxford, 296p

[26] Martodjojo, S., (1984).Evolusi Cekungan Bogor, Jawa Barat, Tesis Doktor, Pasca Sarjana ITB.

[27] Mukhtar, O. dkk. (2015). Manajemen Air Tanah di Cekungan Air Tanah DKI Jakarta.Unpad: Bandung. Seminar Nasional Ke - III.

[28] Nettleton, W.D.. Parsons, R.B., Ness, A.O. and Gelderman, F.W., (1982). Spodosols along the southwest Oregon coast. Soil Sci. Soc. Am. J., 46: 593-598.

[29] Nurrohim, Ahmad, Tjaturahono, BS. dan Wahyu Setyaningsih. (2012). Kajian Intrusi Air laut di Kawasan Pesisir Kecamatan dan Kabupaten 
Rembang. Jurusan Geografi, Fakultas Ilmu Sosial, Semarang: Universitas Negeri Semarang.

[30] PAHIAA (Panitia Ad Hoc Intrusi Air Asin). (1986). Direkrorat Geologi Tata Lingkungan,Jakarta.

[31] Permenkes No. 492 Tahun 2010 mengenai Standar Mutu Air Tanah

[32] Piper, A. M. (1944). A graphic procedure in the geochemical interpretation of water analyses. American Geophysical Union Transactions, V. 25, 914-923.

[33] Samsuhadi. (2009). Pemanfaatan Air Tanah Jakarta. JAI Vol 5. No. 1. ejournal.bppt.go.id.

[34] Sen, Z. (2015). Practical and Applied Hydrogeology. Waltham, UK: Elsevier Stuyfzand, P. J., (1989). A New Classification of Water Types, Regional Characterizationof Water Quality (Proceedings of Baltimore Symposium, May - 1989), IAHS - Publication No 182.

[35] Tikhomirov, V. V. (2016). Hydrogeochemistry Fundamentals and Advances: Mass Transfer and Mass Transport.Willey: Canada

[36] Tirtomihardjo, Haryadi. (2012) Kuantifikasi dan Pemodelan Air Tanah Cekungan Air Tanah Jakarta Provinsi D.K.I Jakarta, Provinsi Jawa Barat, dan Provinsi Banten. PSD Air Tanah dan Geologi Lingkungan: Bandung

[37] Todd (1980). Groundwater Hydrology, 2nd edition

[38] Toth, J. (2016). A Theoretical Analysis of Groundwater Flow in Small Drainage Basin.Canada. Journal of Geophysics Research: Vol 68. No.16

[39] Turkandi, T. dkk. (1992). Peta Geologi Lembar Jakarta dan Kepulauan Seribu, Jawa skala 1:100.000. Bandung : Dit. P3G, Dit. Geologi dan Sumberdaya Mineral.

[40] Van Bemmelen. R. W, (1949). Geology of Indonesia. Vol. 1. General Geology Adjaeent Archipelago. Government office. The Haque

[41] Van Zuidam, et, al (1985). Guide to Geomorphologic aerial photographic interpretation and mampping

[42] Yuli Priyana, (2008). Air Tanah (Groundwater). Diktat Kuliaah, Surakarta: Universitas Muhammadiyah Surakarta

[43] Walton WC. (1970) Groundwater resources evaluation. McGraw Hill Book Co, New York

[44] WHO.(1996).Total dissolved solids in Drinkingwater. Geneva: World Health Organization.

[45] Zamora, R. Harmadi. dan Wildan. (2015). Perancangan Alat Ukur TDS (Total Dissolved Solid) Air dengan Konduktivitas Secara Real Time. Jurnal Sainstek Vol. VII No. 1: 11-15, Juni 201 